\title{
Were the First Lapita Colonisers of Remote Oceania Farmers as Well as Foragers?
}

\author{
Andrew Pawley
}

Archaeological evidence indicates that the first Lapita colonisers of Remote Oceania relied heavily on foraging to sustain themselves, exploiting pristine marine and land resources. Did they also carry with them and establish a range of cultivated tubers and tree crops, as argued by Kirch (1997) and others? Noting the lack of direct evidence for horticulture in Lapita sites in this region, Anderson (2003) suggested that cultigens may not have been introduced until considerably later and then in a piecemeal fashion. This paper examines several lines of evidence that bear on this debate, with particular reference to Vanuatu, Fiji and Tonga. Micro-botanical evidence from Vanuatu indicates that yams, aroids and bananas were among the cultigens introduced very early. Comparative lexical evidence suggests the same for the greater yam, Colocasia taro, two kinds of Musa bananas and the major cultivated tree crops. Archaeological evidence shows that pigs and chickens were present in the earliest sites. Divergence of pottery styles points to loss of regular contact between Lapita communities in Near and Remote Oceania and between major regions of Remote Oceania from 2800 BP onwards, within 100-200 years of first settlement. These factors favour the conclusion that most of the typical Oceanic array of cultivated plants had already been introduced before the loss of regular contact and probably in the first generation or two of settlement.

\section{Introduction}

It is generally accepted that, as well as being skilled fishers and reef foragers, the bearers of the early Western Lapita culture in the Bismarck Archipelago practised horticulture. This is indicated by the presence in certain sites of extensive remains of nuts, seed-pods and husks from cultivated trees, and by linguistic evidence: Proto-Oceanic, the primary language of early Lapita communities in the Bismarcks, retained more than 20 Proto-Malayo-Polynesian terms for cultigens and activities associated with horticulture. However, there is less agreement about the role of horticulture in the economy of the first settlers of Remote Oceania. ${ }^{1}$ This paper addresses two questions: (1) Did the first Lapita colonisers of Remote Oceania rely solely on foraging or were they also farmers? (2) What kinds of evidence bear on this question and how should such evidence be evaluated?

\footnotetext{
1 In contrast to 'Near Oceania', that part of the Southwest Pacific that comprises the closely spaced islands of New Guinea, the Bismarck Archipelago and the Solomon Islands, 'Remote Oceania' consists of the far-flung islands and island groups of the Central Pacific, chiefly those of Te Motu Province in the Solomon Islands, Vanuatu, New Caledonia-Loyalties, Fiji, Polynesia and Micronesia.
} 
Opinions on (1) appear to differ. The following remarks by Kirch and Green represent archaeologists who support the early horticulture hypothesis:

When Lapita populations expanded into Remote Oceania ... they transported a full roster of oceanic crops, including such staples as taro, yam, bananas and breadfruit. Indeed, the very ability to transfer such systems of horticultural production was arguably an essential aspect of the successful Lapita colonization strategy (2001: 121).

Kirch makes an even stronger claim:

Wherever they sailed in Remote Oceania, Lapita groups came fully equipped to establish permanent settlements, carrying with them domesticated animals and planting stocks of tubers, fruit, and tree crops, as well as a sophisticated knowledge of horticulture and plant manipulation (2000: 109).

Proponents of this hypothesis refer, in the first place, to (i) a sizeable array of Proto-Oceanic (POc) reconstructed terms for cultivated plants and gardening activities that have regular reflexes (continuations) widely distributed in daughter languages across Remote Oceania and which imply continuous transmission of these terms from POc to the daughter languages. They also refer to one or more of other kinds of (largely circumstantial) evidence from Remote Oceania, such as (ii) the poverty of native plant and land animal species that would have provided sufficient sources of starch and fat to sustain human colonisers for more than a short period, (iii) maintenance during the early Lapita phase of an exchange network extending from the Bismarcks to Vanuatu that would have enabled transfer of cultivated plants, (iv) deforestation and erosion associated with large-scale clearance during the early stages of settlement, (v) the presence in early Lapita sites of artefacts typically associated with horticulture, including a range of ceramic vessel types, earth ovens, and pits possibly for storage of breadfruit, taro or bananas, and of traces of substantial houses indicating permanent settlement, (vi) skeletal remains of domesticated animals - pigs and chickens - in early Lapita assemblages, and (vii) micro-fossil evidence of food crops including aroids, yam and banana in early Lapita sites in Vanuatu.

A seemingly contrary view has been taken by a number of archaeologists. Several decades ago Groube, writing about Fiji and Tonga, tentatively proposed that:

the Lapita potters, initially at least, had a restricted maritime/lagoon economy and that ... the [later] development or introduction of a more viable horticultural economy enabled them to expand and survive in Fiji and Tonga ... In this conception the Lapita potters would be Oceanic 'strandloopers', who ... expanded ahead of colonisation by agriculturalists (1971: 313).

He based this claim chiefly on the location of Lapita sites in Tonga and Fiji, invariably close to reef flats rich in shellfish, and on the disappearance of concentrated shellfish middens in postLapita sites. Groube interpreted the latter phenomenon as marking 'a shift from reef exploitation to agriculture in the latter half of the first millennium BC' (1971: 311), i.e. several hundred years after first settlement of Fiji and Tonga.

More recently, Anderson (2003) has questioned the notion that, during the initial colonisation of Remote Oceania, foraging alone could not have sustained communities for long periods in environments with few edible plants and land animals. Following Davidson and Leach (2001) he notes that alternative sources of nutrition, especially for the vital fatty acids, were present on Oceanic islands in the form of crabs, immature seabirds, eggs, turtles, lizards and dugong. 'Provided that colonization groups stayed in a 'skimming' mode, taking such resources from one island then moving to the next, non-agricultural coloniation, should have presented no insuperable difficulty. Long-term settlement probably required agriculture but it was not necessary at the beginning' (Anderson 2003: 77). He concludes that: '[a]n effectively foraging economy ... still seems the most probable mode during the dispersal phase in Remote Oceania ... In this matter ... an hypothesis of economic discontinuity seems preferable' (2003: 78). 
I referred above to 'seemingly contrary views' because the two camps have formulated their claims somewhat loosely, and they can be interpreted as making similar claims, differing merely in emphasis. Thus, proponents of the early farming hypothesis do not dispute that the first generation of Lapita colonists of Remote Oceania relied heavily on foraging. For example, Kirch writing of Polynesia says that 'in a fledgling colony's first years, transplanted cultigens could not have provided a sufficient basis for subsistence and the settling party would have to depend heavily on naturally abundant resources' (1984: 84). Conversely, proponents of the early reliance on foraging hypothesis do not categorically exclude horticulture. They simply propose that if it was present initially, it was unimportant. Neither side makes precise claims about how long it was before horticulture replaced foraging as the main source of food.

However, one can formulate a stronger version of the reliance on foraging hypothesis that is clearly distinct from the early farming hypothesis, namely that there was a delay of several generations before most of the Oceanic staple cultigens were introduced. Anderson's observation that foragers could have kept moving to new pristine locations after exhausting natural resources in their current habitat, at least in large islands and island groups, provides a model of how a mobile population could remain foragers for generations.

At any rate, whether or not Lapita colonists could have survived and flourished for several generations without the staple Oceanic cultivated vegetables and fruits, these questions remain: Did the first wave of colonists bring such cultigens with them and if so, which ones? And how long did the reliance on foraging last? The remainder of this paper briefly examines evidence that bears on these questions, with particular reference to Vanuatu, Fiji and Tonga.

\section{Arguments for and against early horticulture}

\section{How long did the reliance on foraging last?}

Beyond the Near Oceania/Remote Oceania divide there is a sharp diminution in the range of native plant and land animal species that would have provided food for the first human colonisers (Green 1991). However, the archaeological record shows that the pioneering Lapita colonists of islands in Remote Oceania were able to exploit an abundance of fish and shellfish, along with turtle, sea and land birds, fruit bats, and other creatures. But how long did this abundance last in any particular habitation area? The record for Vanuatu suggests what Bedford (2006), following Steadman (1998), calls the foraging 'blitzkrieg' soon reduced the abundance. Some readily procurable species became scarce or extinct or (in the case of certain shellfish) smaller. Referring to the immediately post-Lapita site at Arapus, Efate, in Vanuatu, Bedford writes that the faunal remains:

dramatically demonstrate the subsistence strategy of a population on first arrival and how ... very quickly that strategy changed following the depletion of pristine resources ... The first sign of human arrival in the area is evidenced by the build-up of midden deposits directly on top of the former foreshore ... This evidence gives a glimpse of a short time period, before the establishment of horticultural systems, when the population ... was heavily reliant on readily procurable local marine and terrestrial resources (2006: 257).

But just how long was the 'short time period' between abundance and depletion at Arapus? Presumably depletion was a gradual process taking place over several generations or even two or three centuries. The archaeological record is probably not fine-grained enough to trace the chronology of this process more precisely than that. 
Lapita sites at Nukuleka (on the northeast coast of Tongatapu) and elsewhere in Tongatapu and Ha'apai tell a similar story to Arapus. The earliest layers, dating to $c a .2800 \mathrm{BP}$, show an initial reliance on fish, shellfish and wild birds, including species of birds that rapidly became extinct (Shutler et al. 1994; Steadman et al. 1998). In Ha'apai sites, within a few centuries chickens replace wild birds as the most common species in middens, increasing from 24 per cent to 81 per cent of total bird bones (Steadman et al. 1998). In Tonga, the earliest Colocasia pollen is found in Avai'o'vuna Swamp, Vava'u Island, at about 2600 BP, less than two centuries after first human occupation of Vava'u (Fall 2010).

The oldest human skeletal remains found in the Teouma site in Vanuatu show well-marked signs of scurvy, possibly due to a high protein diet, and inadequate consumption of plant foods and/or cooking methods that destroyed the vitamin C (Buckley et al. 2014). Later skeletal remains point to improved health but it is not possible to date this improvement precisely.

\section{Scarcity of direct evidence for horticulture in the archaeological record}

Anderson writes as follows concerning the difficulties of determining the role of cultivated plants in the initial colonisation of Remote Oceania:

Arrival of horticulture with the first colonists is not open to direct demonstration. None of the domestic tubers are yet represented clearly amongst preserved plant remains, especially of nuts, in the Western Lapita waterlogged sites, let alone further east, and, in any event, those remains beg some questions of interpretation, such as how many of them were derived merely from shoreline flotsam ... There are some possible nut-processing implements but the case for tuber gardening anywhere in the early Lapita phase has yet to be made on direct evidence such as pollen, starches, or microbotanical remains ...

The argument has to be carried almost entirely ... by linguistic reconstruction. This method has the advantage that the crops were demonstrably introduced to Remote Oceania and the names are clearly associated through numerous cognates with the species to which they refer ... Thus ProtoOceanic reconstructions for taro, yam, banana and breadfruit were retained almost unchanged into Proto-Polynesian, and much the same is true of horticultural practices. But the strength of this argument is also its weakness. If reconstructed lexemes hardly changed over long periods and across the region, they can offer little indication of the pattern of arrival. The linguistic data, alone, cannot validate the assumption that agriculture was carried by the first, early Lapita colonists of Remote Oceania. It might have arrived later in the Lapita era and never as a package (2003: 77).

Recently, micro-fossil evidence of food crops including aroids, yam and banana has been reported for early Lapita sites in Northern Vanuatu (Horrocks and Bedford 2004, 2010; Horrocks et al. 2009). Although, as Buckley et al. comment, 'it remains to be fully understood how just successful these initial communities were at establishing horticultural and aboricultural crops' (2014: 82), this is direct evidence of early horticulture. The characterisation of the materials as being 'initial' or 'early' in the sequences implies that they fall within the first century or so of settlement.

\section{Forest clearance and erosion associated with large-scale clearance for gardening}

Spriggs (1997) points to a recurrent pattern of deforestation and erosion associated with large scale clearance during the early stages of settlement in Remote Oceania, followed by 'abandonment of an area for sometimes many hundred of years and a later more conservation oriented reuse with continuing occupation'. For example, large-scale clearance of forest on Aneityum, Southern Vanuatu, is evident from around 3000-2900 BP (Hope and Spriggs 1982; Spriggs 1997). This was concentrated in the uplands because the coastal lands were swampy and prone to 
flooding. Although it is impossible to know whether large-scale clearing began with the first generation of settlers or later, the dates are within a century or so of earliest accepted dates for the settlement of Remote Oceania, so the delay can hardly have been a matter of centuries. A similar sequence is evident on Tikopia (Kirch and Yen 1982).

On Totoya Island in the Moala group, Fiji, Clark and Cole (1997) found evidence of forest clearance shortly after first settlement by people with Lapita ceramics, followed by the extension of grasslands and secondary forest.

\section{Domesticated animals}

Neither pigs nor chickens are native to Remote Oceania and their presence in Lapita sites there can be taken as proof of animal husbandry, normally a proxy for horticulture. Although pigs were absent from New Caledonia in prehistoric times, both pigs and chickens are present in early Lapita sites in Santa Cruz, Tikopia, and Vanuatu. There are no pig bones in Lapita sites in Tonga and no well-stratified pig bones in early sites in Fiji.

Bedford states that ' $[\mathrm{t}]$ he archaeological record from Vanuatu indicates that pigs arrived with the earliest colonisers and it seems likely that they spread relatively quickly throughout the archipelago' (2006: 227). '[C]hicken was a consistent component of middens from the earliest layers of the sites' e.g. at Ifo, Malua Bay and Arapus, 'suggesting that it was present in some quantity from initial arrival' (2006: 231). The same applies to Tonga (see below). Chicken bones are present but scarce in Lapita sites in Fiji (Worthy and Clark 2009).

\section{Settlement patterns and artefacts}

Early Lapita settlements in Remote Oceania were typically located on sandy beach terraces close to fringing reefs and fresh water sources. The settlers built substantial wooden houses, indicative of permanent occupation. In early Lapita sites that have yielded a range of artefacts, various items associated with food preparation and cooking are found: ceramic pots for boiling, stone ovens for baking, vegetable scrapers, and pits possibly for storage and fermentation of breadfruit, taro or bananas, as well as adzes, used for clearing land for gardens (Kirch 1997). The presence of permanent settlements and such artefacts is not conclusive evidence for horticulture but it is consistent with it.

\section{Maintenance of a trade network extending from the Bismarcks to Vanuatu during the early Lapita phase}

The early Lapita colonists of Remote Oceania were capable sailors who for a time maintained long-range contacts across island groups separated by hundreds of kilometres. Their mobility is evidenced most conspicuously by their rapid expansion across the Southwest Pacific, with settlement of Reefs-Santa Cruz, Vanuatu, New Caledonia, Fiji and Tonga in the period $3100-2850 \mathrm{BP}$.

There is clear evidence that the colonists for a time maintained a long-distance trade network through which significant quantities of obsidian from Talasea on the Willaumez Peninsula in New Britain were transported to Reefs-Santa Cruz in the Eastern Solomons (Sheppard 1993), smaller but still substantial quantities to Northern and Central Vanuatu (Galipaud et al. 2014; Reepmeyer et al. 2011) and still smaller quantities to New Caledonia and Fiji. Reefs-Santa Cruz sites also contain some low-grade obsidian from the Banks Island and chert from Ulawa and Malaita in the main Solomons group (Spriggs 1997). The Northern and Central Vanuatu sites also include Banks Islands obsidian (Constantine et al. 2015; Reepmeyer et al. 2011) 
Given that Proto-Oceanic speakers in the Bismarck Archipelago cultivated a wide range of crops, and given the exchange connections between the Bismarcks and Remote Oceania at the time of the Lapita dispersal, it might be expected that something as useful as staple food plants would have been carried to Remote Oceania soon after first settlement. How long it would have taken for the full set of Oceanic cultigens to be transported and become established is another matter.

\section{Linguistic evidence}

\section{Proto-Oceanic as the primary language of early Western Lapita communities in the} Bismarck Archipelago

The Oceanic subgroup comprises some 450-500 languages: all the Austronesian languages of Melanesia east of Cenderawasih Bay in New Guinea, all the languages of Micronesia except Chamorro and Palauan, and those of Polynesia. Oceanic is in turn a branch of the MalayoPolynesian (MP) subgroup of Austronesian, which includes all Austronesian languages other than those spoken in Taiwan. The Oceanic languages have undergone a substantial number of innovations apart from the rest of the Austronesian family, pointing to a period, probably a few centuries, of compact unified development in Western Melanesia before they dispersed across the Southwest and Central Pacific. The final stages of this unified development almost certainly took place in the Bismarck Archipelago.

There is good reason to equate speakers of the Austronesian interstage known as Proto-Oceanic (POc) with bearers of the early Western Lapita culture in the Bismarck Archipelago and to equate the spread of Lapita to various parts of Remote Oceania around 3000 BP with the initial spread of Oceanic speakers to these regions. The grounds for this equation have been stated elsewhere (Green 2003; Kirch 1997; Pawley 2007, 2008; Spriggs 1997; Summerhayes 2001) and will not be elaborated here. The Lapita people who first settled Reefs-Santa Cruz, Vanuatu, Fiji and Tonga would have spoken dialects little differentiated from POc.

Dialect diversification within POc probably began with the dispersal of early Western Lapita to various parts of the Bismarcks around $3300 \mathrm{BP}$ (or a bit later - there is currently a re-evaluation of early Lapita dates going on (Petchey et al. 2014: 240)). Blust $(1978,1998)$ has argued that the first split in Oceanic was between the Admiralties languages and the rest. If so, this would indicate that the Admiralties were not the source of the Oceanic languages of Remote Oceania. However, the decisive breakup of POc possibly did not occur until bearers of Lapita first moved beyond the Bismarcks into various parts of Remote Oceania around 3000-2900 BP. 


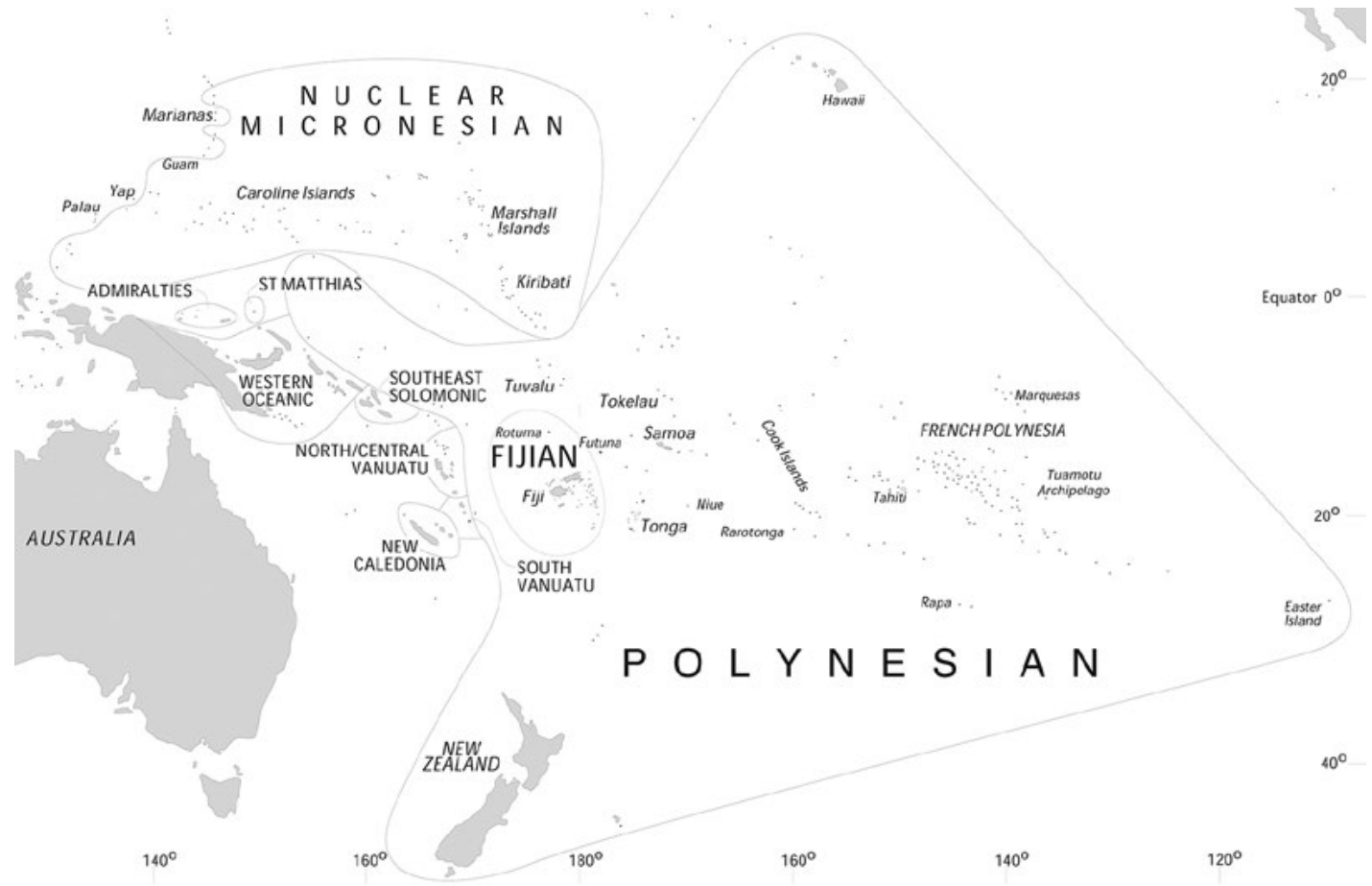

Figure 17.1 The major subgroups of Oceanic.

Source: After Ross et al. 2011, p. 11, reproduced with permission from Pacific Linguistics.

The chief high-order subgroups of Oceanic recognised here are as follows (see Figure 17.1): Admiralty Islands, Mussau, Western Oceanic (comprising the Oceanic languages of New Guinea east of the Sarmi Peninsula, New Britain, New Ireland, Bougainville and the Western Solomons), Southeast Solomonic (Guadacanal, Malaita, Makira), Te Motu (Reefs-Santa Cruz, Utupua, Vanikoro), North-Central Vanuatu, Southern Vanuatu, New Caledonia and the Loyalties, Yapese, Nuclear Micronesian (all languages of Micronesia except Palauan, Chamorro, Yapese, Nukuoro and Kapingamarangi) and Central Pacific (Fijian, Rotuman, Polynesian). The large Western Oceanic group has three major branches: North New Guinea, Papuan Tip and MesoMelanesian. This subgrouping follows Lynch et al. (2002), Ross (1988) and Ross et al. (2011) with some modifications.

\section{Retention of Proto-Oceanic terms for horticulture in Remote Oceanic languages}

There has been extensive reconstruction of terms relating to horticulture for various stages of Austronesian. Most important for our purposes are reconstructions by Blust and Trussel (ongoing) of Proto-Austronesian (PAN), Proto-Malayo-Polynesian (PMP) and POc (see also Blust 1995) and two volumes of essays on the lexicon of POc (Ross et al. 1998, 2008). ${ }^{2}$

PAN and PMP had terms for a number of crops and gardening practices (Blust 1995, 2009). Terms associated with rice and millet cultivation were not preserved in POc but others were. As well as various cultivated plants, these include terms for (swidden) garden, fallow land, uncultivated land, making a garden, clearing vegetation, planting yams, weeding a garden, digging stick or dibble, and garden fence or partition. Many of these terms have regular reflexes in major subgroups of Remote Oceania, with the partial exception of Te Motu, where data are scarce, and Nuclear Micronesian, where many POc terms to do with horticulture have been lost.

2 Two other volumes of essays have been published in this series but the reconstructions in these do not relate to horticulture. 
A selection of reconstructions with supporting cognates follows. Reflexes (inherited continuations) of each reconstructed term in daughter languages are arranged by subgroup. Where there are reflexes of a POc term in many languages only a small selection is cited, enough to roughly indicate which subgroups have reflexes. The following abbreviations are used for when citing reconstructed etyma, reflexes and sources.

\section{Abbreviations}

ACD Austronesian Comparative Dictionary (Blust and Trussel in progress)

Adm Admiralties

Fij Fijian and Rotuman

Mic Nuclear Micronesian

MM Meso-Melanesian

$\mathrm{N} \quad$ noun

NCal New Caledonian

PAN Proto-Austronesian

PMP Proto-Malayo-Polynesian

Pn Polynesian

POc Proto Oceanic

PPn Proto-Polynesian

PT Papuan Tip

PWOc Proto Western Oceanic

SES Southeast Solomonic

SV Southern Vanuatu

V verb

VT transitive verb

Tubers

Yams

Several terms for yam taxa are reconstructable for POc: * $q u p i$ 'Dioscorea alata, greater yam' (continuing PAn ${ }^{*} q u b i$ ) is found almost throughout Island Melanesia and Polynesia. Terms for other yam taxa include * $p^{w}$ atika ' $D$. bulbifera, potato yam', *pwasepe 'D. alata', *udu(r,R) 'k.o. greater yam', *mwaruqen 'k.o. yam, wild yam (?)'. A term for Dioscorea esculenta, lesser yam, *kamisa or *mamisa, is reconstructable for PWOc but not for POc, because it lacks reflexes in Remote Oceanic languages. D. pentaphylla is present throughout Melanesia but no POc name can be reconstructed. Here I give only a selection of reflexes only for ${ }^{*} q u p i$.

PMP *qubi ‘yam’ (ACD)

POc *qupi 'Dioscorea alata, greater yam'; (2) 'generic for yams' (Ross et al. 1998)

$\begin{array}{llll}\text { Adm } & \text { Penchal } & k u p & \text { (1) 'long yam' } \\ \text { NNG } & \text { Malasaga } & k u i-k u i & \text { (1) 'greater yam'; (2) 'generic' } \\ \text { PT } & \text { Iduna } & k u v i & \text { (1) 'greater yam'; (2) 'generic' } \\ \text { MM } & \text { Tolai } & a-u p & \text { (1) 'greater yam'; (2) 'generic' } \\ \text { MM } & \text { Marovo } & u v i & \text { (1) 'greater yam'; (2) 'generic' } \\ \text { TM } & \text { Tanema } & u v a & \text { 'yam' } \\ \text { SES } & \text { Arosi } & u b i & \text { (1) 'greater yam'; (2) 'generic' } \\ \text { SV } & \text { Lenakel } & n-u w & \text { (1) 'greater yam'; (2) 'generic' }\end{array}$




$\begin{array}{llll}\text { NCal } & \text { Jawe } & \text { kuic } & \text { (1) 'greater yam'; (2) 'generic' } \\ \text { Fij } & \text { Wayan } & u v i & \text { (1) 'greater yam'; (2) 'generic' } \\ \text { Pn } & \text { Tongan } & \text { ?ufi } & \text { (1) 'greater yam'; (2) 'generic' } \\ \text { Pn } & \text { Futunan } & \text { ?ufi } & \text { (1) 'greater yam'; (2) 'generic' }\end{array}$

Yam-growing is a demanding enterprise, involving clearing, planting, weeding and a good understanding of the seasons. As yams are a seasonal crop, in times of shortage Oceanic yam growers relied on other staples and/or on storage of yams in storage houses.

\section{Taro}

One POc generic term for Colocasia esculenta continues a PMP etymon.

PMP *tales 'taro, Colocasia esculenta' (ACD)

POc *talo(s) 'taro, Colocasia esculenta' (Ross et al. 2008)

$\begin{array}{llll}\text { NNG } & \text { Manam } & \text { taro } & \text { 'taro, Colocasia esculenta' } \\ \text { PT } & \text { Motu } & \text { talo } & \text { 'taro, Colocasia esculenta' } \\ \text { MM } & \text { Roviana } & \text { talo } & \text { 'taro, Colocasia esculenta' } \\ \text { SES } & \text { Lau } & \text { alo } & \text { 'taro (generic)' } \\ \text { SES } & \text { Kwaio } & \text { alo } & \text { 'taro, Colocasia esculenta' } \\ \text { NCV } & \text { S. Efate } & (n) \text { tal } & \text { 'taro, Colocasia esculenta' } \\ \text { SV } & \text { Anejom } & n \text {-tal } & \text { 'taro, Colocasia esculenta' } \\ \text { Fij } & \text { Bauan } & \text { dalo } & \text { 'taro, Colocasia esculenta' } \\ \text { Pn } & \text { Samoan } & \text { talo } & \text { 'taro, Colocasia esculenta' }\end{array}$

Another term, POc ${ }^{*} m^{w} a p o(q)$, has widely replaced ${ }^{*}$ talo(s) as the generic for C. esculenta in Western Oceanic languages. Its few reflexes in Remote Oceania generally refer to a variety of C. esculenta and that may have been the case in POc.

Although well attested in Near Oceania, in Remote Oceania a POc term for taro seedling has known reflexes only in New Caledonian languages.

POc *up(e,a) 'taro seedling' (Ross et al. 2008)

$\begin{array}{llll}\text { NNG } & \text { Tami } & \text { uwe } & \text { 'taro seedling' } \\ \text { PT } & \text { Are } & \text { ube } & \text { 'taro tops for planting' } \\ \text { PT } & \text { Motu } & \text { uhe } & \text { 'the end of yam, kept for planting, any such seed' } \\ \text { SES } & \text { Arosi } & \text { uha } & \text { 'taro sp.' } \\ \text { NCal } & \text { Pwapwa } & \text { upe } & \text { 'taro seedling', } \\ \text { NCal } & \text { Yuanga } & \text { uva } & \text { 'taro seedling' }\end{array}$

\section{Fruit crops}

Terms for a number of cultivated fruit bearing trees and tree-like plants are reconstructable for POc (Ross et al. 2008, ch. 11) with widespread reflexes in Remote Oceania, indicating continuity as far as Fiji and Polynesia. These include terms for breadfruit and bananas (see below), * quRis 'Spondias cytherea, Polynesian plum', *kapika 'Syzygium malaccense, Malay apple', *tawan 'Pometia pinnata, Ocean lychee', *wai, *waiwai 'Mangifera sp., mango', *molis 'citrus fruit', *natuq 'Burckella obovata'. Because of space limitations, I will give cognate sets here only for breadfruit and bananas. 


\section{Breadfruit}

Two well-supported terms for Artocarpus altilis, *kuluR (with variant *kunuR) and *baReko, are attributable to POc. The first of these continues a PMP antecedent.

PMP *kuluR 'breadfruit, Artocarpus altilis' (ACD)

POc *kuluR 'breadfruit, Artocarpus altilis' (Ross et al. 2008)

$\begin{array}{llll}\text { Adm } & \text { Mussau } & \text { ulu } & \text { 'breadfruit' } \\ \text { Adm } & \text { Titan } & \text { kul } & \text { 'breadfruit' } \\ \text { NNG } & \text { Gedaged } & \text { ul } & \text { 'breadfruit' } \\ \text { NNG } & \text { Manam } & \text { kulu } & \text { 'breadfruit' } \\ \text { MM } & \text { Vitu } & \text { kulu } & \text { 'breadfruit' } \\ \text { MM } & \text { Nakanai } & \text { ulu } & \text { 'breadfruit' } \\ \text { NCal } & \text { Pije } & \text { cin } & \text { 'breadfruit' } \\ \text { NCal } & \text { Iaai } & \text { i-oun } & \text { 'breadfruit' } \\ \text { Fij } & \text { Wayan } & \text { kulu } & \text { 'breadfruit' } \\ \text { Pn } & \text { Samoan } & \text { ?ulu } & \text { 'breadfruit' }\end{array}$

POc *baReko 'breadfruit, Artocarpus altilis' (Ross et al. 2008)

$\begin{array}{llll}\text { PT } & \text { Tawala } & \text { beleha } & \text { 'breadfruit' } \\ \text { PT } & \text { Lala } & \text { bale?o } & \text { 'sago palm' } \\ \text { MM } & \text { Tigak } & \text { bego } & \text { 'breadfruit' } \\ \text { MM } & \text { Nehan } & \text { bario } & \text { 'breadfruit' } \\ \text { TM } & \text { Tanema } & \text { baleo } & \text { 'breadfruit' } \\ \text { SES } & \text { Gela } & \text { bale?o } & \text { 'pair of breadfruit tied together' } \\ \text { SES } & \text { Bauro } & \text { pare?o } & \text { 'breadfruit' } \\ \text { NCV } & \text { Mota } & \text { pego } & \text { 'breadfruit' } \\ \text { NCV } & \text { NE Ambae } & \text { baego } & \text { 'breadfruit' }\end{array}$

Ross (2008: 282) notes that reflexes of *kuluR (with variant *kunuR) and ${ }^{*} b a R e k o$ are almost in complementary distribution, geographically. The most widespread and frequently reflected term is * kuluR. This has reflexes in the Admiralties and Mussau, North New Guinea, Papuan Tip, New Caledonia, Fiji and Western Polynesia. The variant * $k u n u R$ is reflected in North New Guinea and in the Ngero-Vitiaz group of west New Britain and the Vitiaz Straits. Reflexes of *baReko are found in New Ireland, Northwest Solomons, Southeast Solomons, Te Motu, and in both North-Central Vanuatu and Southern Vanuatu.

Ross (2008) concludes that the usual term for breadfruit in POc was *kuluR and this was carried into Remote Oceania by the first Oceanic-speaking colonists but was later replaced by ${ }^{*} b a R e k o$ in a block extending from New Ireland to Vanuatu. The fact that reflexes of *baReko generally show regular sound correspondences suggests that the replacement occurred quite soon after the initial dispersal of Oceanic dialects to Remote Oceania. Matthew Spriggs (pers. comm.) suggests that the spread of *baReko probably occurred very early, when the Lapita exchange network was still operating, because immediately after the Lapita period, Southern Vanuatu and Central and Northern Vanuatu pottery styles diverge markedly from each other (Bedford 2006).

Another generic name for breadfruit, ${ }^{*} b e t a$, has replaced ${ }^{*} k u l u R$ and ${ }^{*} b a R e k o$ as the generic in certain languages of the Solomons and Vanuatu. Reflexes of yet another term for A. altilis, ${ }^{*}$ maRi, are limited to South Vanuatu, Polynesia and Micronesia, and cannot be attributed to POc. 


\section{Bananas}

Of the two principal POc reconstructions for banana, one, * $p u d i$, continues a PMP etymon.

PMP *punti 'banana' (ACD)

POc *pudi 'banana, Musa cultivars' (Ross et al. 2008)

\begin{tabular}{|c|c|c|c|}
\hline Adm & Mussau & uri & 'banana' \\
\hline Adm & Seimat & pudi & 'Musa sp.' \\
\hline NNG & Maenge & puri & 'banana' \\
\hline NNG & Gitua & pudi & 'banana' \\
\hline $\mathrm{PT}$ & Tubetube & $u d i$ & 'banana' \\
\hline MM & Tigak & $u r$ & 'banana' \\
\hline MM & Bulu & vudi & 'banana' \\
\hline TM & Aiwoo & no-u & 'banana' \\
\hline SES & Gela & vudi & 'banana' \\
\hline SES & Sa’a & huti & 'banana' \\
\hline $\mathrm{NCV}$ & Uripiv & $n a-v i j$ & 'banana' \\
\hline $\mathrm{NCV}$ & Port Sandwich & $n a-v \ddot{u} c$ & 'banana' \\
\hline SV & Sye & no-voh & 'banana' \\
\hline $\mathrm{NCal}$ & Pije & piji(y) & 'Musa paradisica' \\
\hline $\mathrm{NCal}$ & Iaai & $o$-vic & 'banana' \\
\hline Mic & Mokilese & wus & 'banana' \\
\hline Mic & Ponapean & $u: t$ & 'banana' \\
\hline Fij & Wayan & vudi & 'banana' \\
\hline $\mathrm{Pn}$ & Tongan & fusi & 'banana' \\
\hline
\end{tabular}

POc *joRaga 'banana, Fe'i (?) cultivars' (Ross et al. 2008)

$\begin{array}{llll}\text { NNG } & \text { Middle Watut } & \text { cok } & \text { 'banana' } \\ \text { NNG } & \text { Patep } & \text { jog } & \text { 'banana (generic), Musa sapientum' } \\ \text { MM } & \text { Vaghua } & \text { soga } & \text { 'banana' } \\ \text { SES } & \text { Arosi } & \text { toraga } & \text { 'banana' } \\ \text { NCV } & \text { Raga } & \text { hoaga } & \text { 'kind of banana' } \\ \text { NCV } & \text { Uripiv } & \text { jok } & \text { 'Musa troglodytarum' } \\ \text { Fij } & \text { Bauan } & \text { soaga } & \text { 'banana, Musa fehi' } \\ \text { Pn } & \text { Samoan } & \text { soa? } & \text { 'mountain plantain, Musa troglodytarum' }\end{array}$

Several terms for varieties of banana can be attributed to POc: * sakup 'k.o. cooking banana, with long fruit', *bwera 'Musa cultivar', *baqun 'Musa cultivar'.

\section{Gardens and gardening activities}

Aside from plant taxa, a number of POc terms relating to gardens and gardening activities can be reconstructed. Several of these, including *quma 'a garden, work a garden', *topa 'land cleared for a garden', *talu( $n$ ) 'fallow land', *qutan 'bushland', and *asok 'dibble, plant seeds with a dibble', have PAN and/or PMP antecedents.

PAN *qumah (N) 'swidden', (V) 'work a swidden' (ACD)

POc *quma (N) 'garden', (V) 'to clear land for a garden' (Ross et al. 1998) 


$\begin{array}{llll}\text { NNG } & \text { Adzera } & \text { gum } & \text { 'garden' } \\ \text { NNG } & \text { Gedaged } & \text { uma } & \text { 'garden, cultivated land' } \\ \text { PT } & \text { Molima } & \text { 'uma } & \text { 'planted garden' } \\ \text { PT } & \text { Motu } & \text { uma } & \text { 'garden; enclosed, cultivated plot' } \\ \text { MM } & \text { Tolai } & \text { uma } & \text { 'garden' } \\ \text { MM } & \text { Roviana } & \text { uma } & \text { 'make a garden' } \\ & & \text { in-uma } & \text { 'a garden' } \\ \text { SES } & \text { Gela } & \text { uma } & \text { 'clear bush in making a garden' } \\ \text { NCV } & \text { Mota } & \text { umwa } & \text { 'clear growth from a garden, first stage of preparation' } \\ \text { NCV } & \text { Nguna } & \text { uma } & \text { 'cut bush, clear land' } \\ \text { Fij } & \text { Wayan } & \text { uma(ni) } & \text { 'turn the soil over' }\end{array}$

PMP *talun 'fallow land' (ACD)

POc * $\operatorname{talu(n)~'fallow~land,~land~returning~to~secondary~growth'~(Ross~et~al.~1998)~}$

\begin{tabular}{|c|c|c|c|}
\hline \multirow{3}{*}{$\begin{array}{l}\text { SES } \\
\text { SES }\end{array}$} & Gela & talu & 'forest land which has been previously cultivated' \\
\hline & Kwaio & alu & 'garden of second or third crop' \\
\hline & & alu sisi & 'old garden returning to secondary growth' \\
\hline SES & Sa’a & aru & 'last year’s yam garden’ \\
\hline SES & Arosi & aru & $\begin{array}{l}\text { 'overgrown garden; land formerly used for a garden; } \\
\text { a dug garden' }\end{array}$ \\
\hline Pn & Niuean & talu-talu & 'land out of cultivation' \\
\hline Pn & Rennellese & tagu-tagu & 'begin to be bush-covered, of a fallow garden' \\
\hline $\mathrm{Pn}$ & Maori & taru-taru & 'weeds, herbs' \\
\hline
\end{tabular}

Although the next POc term, *topa 'garden land', has known reflexes only in Fijian languages within Oceanic, it continues a PMP etymon and so must be attributed to POc and must have been part of the vocabulary carried to Remote Oceania.

PAN *tebaS 'clear vegetation' (ACD)

POc *topa 'land cleared for a garden', or 'land formerly planted as a garden' (Ross et al. 1998)

$\begin{array}{llll}\text { Fij } & \text { Bauan } & \text { tova } & \text { 'flat piece of land, formerly planted with yams' } \\ \text { Fij } & \text { Wayan } & \text { tova-tova } & \text { 'garden plantation' }\end{array}$

The next cognate set is included, beside the previous two, to support a three-way contrast between terms for land under cultivation $\left({ }^{*}\right.$ quma), fallow land $\left({ }^{*}\right.$ talu $\left.(n)\right)$ and bushland (qutan), in POc and some of its daughters.

PAN *quCaN'scrub-land, bush' (ACD)

POc *qutan 'bushland, hinterland' (Ross et al. 1998)

\begin{tabular}{|c|c|c|c|}
\hline Adm & Mussau & utana & 'garden' \\
\hline NNG & Manam & (a) uta & 'inland' \\
\hline PT & Motu & $u d a$ & 'bush, forest' \\
\hline PT & Bwaidoga & yudana & 'forest' \\
\hline SES & Tolo & uta & 'garden’ \\
\hline NCV & Mota & uta & 'bush, forest, unoccupied land; the inland country' \\
\hline NCV & Nguna & uta & 'inland' \\
\hline Mic & Kosreaean & $w \partial t$ & 'area inland or towards the mountains' \\
\hline
\end{tabular}




$\begin{array}{llll}\text { Fij } & \text { Rotuman } & \text { ufa } & \text { 'land (from sea), interior (from coast)' } \\ \text { Pn } & \text { Tongan } & \text { ?uta } & \text { 'land (from sea), inland (from shore) }\end{array}$

PMP *hasek 'dibble, plant seeds with a dibble stick' (ACD)

POc *asok 'plant (yams) in holes in the ground' (Ross et al. 1998)

\begin{tabular}{|c|c|c|c|}
\hline MM & Notsi & soka & 'plant (sweet potato etc.)' \\
\hline MM & Patpatar & soh & 'plant (sweet potato etc.)' \\
\hline MM & Bali & $v-a z o \gamma-i$ & 'plant (tuber etc.)' \\
\hline NNG & Malai & $p-a z o g-i$ & 'plant (tuber etc.)' \\
\hline PT & Motu & h-ado & 'plant (tuber etc.)' \\
\hline SES & Sa'a: & ato(taha) & 'throw the first yam set into the hole (of priest)' \\
\hline SES & Ulawa & ato $(n i w a ? a)$ & 'throw the yams into the holes' \\
\hline \multirow[t]{2}{*}{ SES } & Arosi & ato & 'distribute yams in holes for planting' \\
\hline & & atoato & $\begin{array}{l}\text { 'lay in rows, mark out thus, as a garden with } \\
\text { horizontal poles' }\end{array}$ \\
\hline Mic & Woleaian & $f$-atox-i & 'plant s.t.' \\
\hline
\end{tabular}

PMP *babaw (V) 'weed (a garden)' (ACD)

POc *papo (V) 'weed (a garden)' (Ross et al. 1998)

\begin{tabular}{|c|c|c|c|}
\hline NNG & Yabem & waong & 'weed' \\
\hline PT & Gapapaiwa & vao & (VT) 'grow s.t., plant s.t.'; (N) 'garden’ \\
\hline SES & Gela & vavo & (VT) 'weed s.t.' \\
\hline SES & Lau & fofo & 'weed with a knife' \\
\hline SES & Sa’a & hoho & $\begin{array}{l}\text { 'cut undergrowth' (hoho-la 'a garden cleared } \\
\text { for yams') }\end{array}$ \\
\hline SES & Arosi & haho & (V) 'weed' \\
\hline NCV & Mota & wowo(r) & (V) 'weed' \\
\hline Fij & Bauan & vovo & 'dig the ground between yam mounds' \\
\hline
\end{tabular}

POc *bayat $(\mathrm{N})$ 'fence, boundary marker'; (VT) *bayat-i 'make a garden boundary'

\begin{tabular}{|c|c|c|c|}
\hline \multirow[t]{2}{*}{ PT } & \multirow[t]{2}{*}{ Gumawana } & bayata & 'garden boundary made by terracing rocks \\
\hline & & bayas $-i$ & 'make a garden boundary' \\
\hline PT & Iduna & $b a i$ & 'stick used as garden boundary' \\
\hline \multirow[t]{2}{*}{ MM } & Tolai & bait & (V) 'enclose with a fence' \\
\hline & & ba-bait & $(\mathrm{N})$ 'fence' \\
\hline SES & Arosi & $b a i-b a i$ & 'large logs put round a finished garden' \\
\hline Fij & Bauan & $b a i$ & 'fence around a garden or town' \\
\hline Pn & E. Futunan & pae & 'raised stone platform of house or grave' \\
\hline $\mathrm{Pn}$ & W. Futunan & bae & 'a stone fence' \\
\hline
\end{tabular}

\section{Terms for pig}

There is some lexical evidence that the first Oceanic speakers in Remote Oceania practised pig husbandry. Three terms for 'pig' are attributable to POc (Ross et al. 2011: 237-240), but only two of these are retained in Remote Oceanic languages. POc *boRok continues PAN *beRek 
'domesticated pig' (ACD). It is reflected in all major subgroups in Near Oceania but appears in Remote Oceanic only in North-Central Vanuatu and Western Fijian. The reflexes in these languages show loss of ${ }^{*} R$ and, in some cases, replacement of ${ }^{*} b$ by a labiovelar or velar stop.

PAN *beRek 'domesticated pig' (ACD)

POc *boRok 'pig, Sus scrofa' (all reflexes glossed 'pig' unless otherwise indicated)

$\begin{array}{lll}\text { Adm } & \text { Seimat } & \text { pou } \\ \text { Adm } & \text { Nyindrou } & \text { bou } \\ \text { NNG } & \text { Manam } & \text { boro } \\ \text { NNG } & \text { Mumeng } & \text { bwok } \\ \text { PT } & \text { Tubetube } & \text { buluka } \\ \text { PT } & \text { Wedau } & \text { poro } \\ \text { MM } & \text { Bali } & \text { boroko } \\ \text { MM } & \text { Nakanai } & \text { boro } \\ \text { SES } & \text { Gela } & \text { bolo } \\ \text { NCV } & \text { Mota } & \text { pwoe } \quad \text { pig, male pig, barrow pig' } \\ \text { NCV } & \text { Kiai } & \text { poe } \\ \text { NCV } & \text { Raga } & \text { boe } \\ \text { Fij } & \text { Wayan } & \text { qoo }\end{array}$

In some North-Central and Southern Vanuatu languages * $b o R o k$ is replaced by reflexes of POc ${ }^{*} b(o, u) k a s(i)$ 'pig, boar'. PPn *puaka may reflect the latter term, with *bukas becoming *puka, followed by anticipatory insertion of $a$. The Polynesian term has been borrowed as vuaka in some Eastern Fijian dialects.

On Anderson's argument regarding delayed introduction, the lexical evidence - continuity in an extensive set of POc terms relating to horticulture - is consistent with the hypothesis that the first Lapita settlers in Vanuatu, Fiji and Western Polynesia carried with them an array of crops, including taro, yams, bananas and some tree crops. Against this, Anderson (2003) argues that the lexical evidence is also compatible with the hypothesis that some or all of these crops were introduced at a later date, because the form and meaning of many of the POc terms would have remained largely unchanged for centuries in the speech of the Lapita colonists.

His general point is well taken. However, there are a few exceptions to the generalisation. Some POc terms have undergone regular sound changes in daughter languages that probably occurred within a few centuries after the Oceanic dispersal. These sound changes provide a diagnostic for distinguishing late borrowings from retentions. For example, POc * $q u R i$ 'Polynesian plum' is reflected in Proto-Central Pacific and PPn as ${ }^{*} w i$, showing regular loss of ${ }^{*} R$ and final ${ }^{*} s$ and reduction of initial syllabic ${ }^{*} u$ to non-syllabic ${ }^{*} w$. The Central Pacific form could not have been borrowed from, say, Vanuatu or Solomon Islands languages, which retain ${ }^{*} R$ and ${ }^{*} u$ in this item. A case of a somewhat different kind is the preservation of POc word initial and medial ${ }^{*} q$ as glottal stop (2) in Tongan and a few other Polynesian languages, in contrast to its loss in all Southeast Solomonic languages, almost all Vanuatu languages and all Fijian languages. The fact that POc *qupi 'yam, D. alata' is reflected in Tongan as ?ufi, rather than $u f$, favours the view that the Tongan term is a direct retention from POc and not a borrowing from, say, a Vanuatu or Fijian source. 
More generally, the sheer number of POc terms for cultigens and cultivation practices retained by some of the languages of Vanuatu, Fiji and Polynesia suggests to me that most of these terms, and therefore the array of crops and practices, were carried to these regions when or soon after the first Lapita colonists settled them.

There is archaeological evidence in favour of this last conclusion. The exchange network linking Lapita communities in Near and Remote Oceania did not last long - not more than a century or two after initial settlement of Remote Oceania about 3000-2900 BP. By 2700 BP, divergence in pottery styles between regions indicates loss of regular contact between Near and Remote Oceania and between regions within Remote Oceania. Fiji and Tonga drop out of contact first, along with New Caledonia, and Southern Vanuatu soon begins to diverge from Northern and Central Vanuatu (Bedford 2006; Bedford and Clark 2001). The implication is that most of the cultigens must have been transported to Vanuatu and on to New Caledonia, Fiji and Tonga before the Lapita exchange system broke down.

\section{Conclusion}

Is the available evidence sufficient to give a confident answer to the question: Did the first generation of Lapita colonists in Vanuatu, Fiji and Western Polynesia bring cultigens with them and, if so, which ones?

I don't think we can completely dismiss Anderson's agnosticism on this matter. But it seems to me that even though foraging was initially much the more important source of food, various lines of evidence, taken together, indicate horticulture was practised from a very early period, and probably from the beginning of settlement. The micro-botanical evidence from Vanuatu indicates that yams, aroids and bananas were among the cultigens introduced very early. The linguistic evidence suggests the same for the greater yam, Colocasia taro, two kinds of Musa bananas and the major cultivated tree crops. Then there is archaeological evidence, chiefly divergence in pottery styles, which points to loss of regular contact between Lapita communities in Near and Remote Oceania and between major regions of Remote Oceania from 2700 BP onwards, within 100-300 years of first settlement. This favours the conclusion that most of the typical Oceanic array of cultivated plants had already been introduced and established before regular contact was broken.

Does the archaeological evidence allow precise estimates of how long the early Lapita reliance on foraging lasted in Vanuatu, Fiji or Tonga? Reports for each region generally speak of a swift decline but refrain from more precise estimates. Perhaps it is wrong to frame the question so broadly. We cannot assume that the chronology was the same for all environments (in some islands resources for foraging were quite impoverished at the time of first settlement) or that there was a sharp transition. While some kinds of native fauna probably diminished quickly, e.g. turtle, land birds such as pigeons and megapodes, and fruit bats; in the case of shellfish and other reef invertebrates, it is more likely that there was a gradual decline over many generations. In any case, during the first few generations, when the human population densities were still low, people would have been able to move on to new and pristine sites. 


\section{Acknowledgements}

It is a pleasure to offer this paper to Peter Bellwood and to recall that we began our careers together in the Department of Anthropology, University of Auckland, in the 1960s, before he became famous. Robert Blust, David Burley, Malcolm Ross and Matthew Spriggs provided helpful comments on a draft of this paper.

\section{References}

Anderson, A. 2003, Initial human dispersal in Remote Oceania: Pattern and explanation. In C. Sand (ed.), Pacific Archaeology: Assessment and Prospects, pp. 71-84. Numea: Le Cahiers de l'Archeologie en Novelle-Caledonie.

Bedford, S. 2006. Pieces of the Vanuatu Puzzle: Archaeology of the North, South and Centre. Terra Australis 23. Canberra: Pandanus Books, Research School of Pacific and Asian Studies, The Australian National University.

Bedford, S. and G. Clark. 2001. The rise and rise of the incised and applied relief tradition: A review and reassessment. In G.R. Clark, A.J. Anderson and T .Vunidilo (eds), The Archaeology of Lapita Dispersal in Oceania, pp. 61-74. Terra Australis 17. Canberra: Pandanus Books, The Australian National University.

Blust, R.A. 1978. The Proto-Oceanic Palatals. Auckland: Polynesian Society.

1995. The prehistory of the Austronesian-speaking peoples. Journal of World Archaeology 9(4): 453-510.

1998. A note on higher-order subgroups in Oceanic. Oceanic Linguistics 37(1):1 82-188.

—. 2009. The Austronesian Languages. Canberra: Pacific Linguistics.

Blust, R.A. and S. Trussel. ongoing. Austronesian Comparative Dictionary. www.trussel2.com/ACD/.

Buckley, H.R., R. Kinaston, S.E. Halcrow, A. Foster, M. Spriggs and S. Bedford. 2014. Scurvy in a tropical paradise? Evaluating the possibility of infant and adult vitamin $\mathrm{C}$ deficiency in the Lapita skeletal sample of Teouma, Vanuatu, Pacific Islands. International Journal of Paleopathology 5: 72-85. doi.org/10.1016/j.ijpp.2014.03.001.

Clark, G.R. and A.O. Cole. 1997. Environmental change and human prehistory in the Central Pacific: Archaeological and palynological investigations on Totoya Island, Fiji. Report submitted to the Fiji Museum, Suva.

Constantine, A., C. Reepmeyer, S. Bedford, M. Spriggs and M. Ravn. 2015. Obsidian distribution from a Lapita cemetery sheds light on its value to past societies. Archaeology in Oceania 50(2): 111-116. doi.org/10.1002/arco.5064.

Davidson, J.M. and F. Leach. 2001. The strandlooper concept and economic naivety. In G.R. Clark, A.J. Anderson and T. Vunidilo (eds), The Archaeology of Lapita Dispersal in Oceania, pp. 115-123. Terra Australis 17. Canberra: Pandanus Books, The Australian National University.

Fall, P.L. 2010. Pollen evidence for plant introductions in a Polynesian tropical island ecosystem, Kingdom of Tonga. In S. Haberle, J. Stevenson and M. Prebble (eds), Altered Ecologies: Fire, Climate and Human Influence on Terrestrial Landscapes, pp. 253-271. Terra Australis 32. Canberra: ANU E Press. 
Galipaud, J.-C., C. Reepmeyer, R. Torrence, S. Kelloway and P. White. 2014. Long-distance connections in Vanuatu: new obsidian characterisations for the Makué site, Aotrie Island. Archaeology in Oceania 49: 110-116. doi.org/10.1002/arco.5030.

Green, R.C. 1991. Near and Remote Oceania - disestablishing 'Melanesia' in culture history. In A. Pawley (ed.), Man and a Half: Essays in Pacific Anthropology and Ethnobiology in Honour of Ralph Bulmer, pp. 491-502. Auckland: Polynesian Society.

- 2003. The Lapita horizon and traditions - signature for one set of oceanic migrations. In Sand (ed.), Pacific Archaeology: Assessments and prospects (Proceedings of the Conference for the 50th Anniversary of the First Lapita Excavation. Koné Nouméa 2002), pp. 95-120. Nouméa: Les Cahiers de l'archéologie en Nouvelle-Caledonie 15.

Groube, L.M. 1971. Tonga, Lapita pottery and Polynesian origins. Journal of the Polynesian Society 80(3): 278-316.

Hope, G. and M. Spriggs. 1982. A preliminary pollen sequence from Aneityum Island, Southern Vanuatu. Bulletin of the Indo-Pacific Prehistory Association 3: 88-92. doi.org/10.7152/bippa. v3i0.11194.

Horrocks, M. and S. Bedford. 2004. Microfossil analysis of Lapita deposits in Vanuatu reveals introduced Araceae(aroids). Archaeology in Oceania 39: 67-74.

- 2010. Introduced Dioscorea spp. starch in Lapita and later deposits, Vao Island, Vanuatu. New Zealand Journal of Botany 48: 179-183. doi.org/10.1080/0028825X.2010.502238.

Horrocks, M., S. Bedford and M. Spriggs. 2009. A short note on banana (Musa) phytoliths in Lapita, immediately post-Lapita and modern period archaeological deposits from Vanuatu. Journal of Archaeological Science 36: 2048-2054. doi.org/10.1016/j.jas.2009.05.024.

Kirch, P.V. 1984. The Evolution of the Polynesian Chiefdoms. Cambridge: Cambridge University Press.

— 1997. The Lapita Peoples: Ancestors of the Oceanic World. Oxford: Blackwell.

- 2000. On the Road of the Winds: An Archaeological History of the Pacific Islands before European Contact. Berkeley, Los Angeles, London: University of California Press.

Kirch, P.V. and R.C. Green. 2001. Hawaiki, Ancestral Polynesia: An Essay in Historical Reconstruction. Cambridge: Cambridge University Press. doi.org/10.1017/CBO9780511613678.

Kirch, P.V. and D.E. Yen. 1982. Tikopia: The Prehistory and Ecology of a Polynesian Outlier. Bernice P. Bishop Museum Bulletin 238. Honolulu: Bishop Museum.

Lynch, J., M. Ross and T. Crowley. 2002. The Oceanic Languages. London: Curzon.

Pawley, A. 2007. The origins of early Lapita culture: The testimony of historical linguistics. In S. Bedford, S. Christophe and P.S. Connaughton (eds), Oceanic Explorations: Lapita and Western Pacific Settlement, pp. 17-49. Terra Australis 26. Canberra: ANU E Press.

- 2008. Where and when was Proto Oceanic spoken? Linguistic and archaeological evidence. In A.L. Yuri and K.O. Alexander (eds), Language and Text in the Austronesian World. Studies in Honour of Ulo Sirk, pp. 47-71. Munich: Lincom Europa.

Petchey, F., M. Spriggs, S. Bedford, F. Valentin and H. Buckley. 2014. Radiocarbon dating of burials from the Teouma Lapita cemetery, Efate, Vanuatu. Journal of Archaeological Science 50: 227-242. doi. org/10.1016/j.jas.2014.07.002. 
Reepmeyer, C., M. Spriggs, S. Bedford and W. Ambrose. 2011. Provenance and technology of lithic artefacts from the Teouma Lapita site, Vanuatu. Asian Perspectives 49(1)(for 2010): 205-225.

Ross, M. 1988. Proto Oceanic and the Austronesian Languages of Western Melanesia. Monograph no. 98 Canberra: Pacific Linguistics.

Ross, M., A. Pawley and M. Osmond (eds). 1998. The Lexicon of Proto Oceanic: The Culture and Environment of Ancestral Oceanic Society vol. 1. Material Culture. PL C-152. Canberra: Pacific Linguistics.

— (eds). 2008. The Lexicon of Proto Oceanic: The Culture and Environment of Ancestral Oceanic Society vol. 3. Plants. PL 599. Canberra: Pacific Linguistics.

(eds). 2011. The Lexicon of Proto Oceanic: The Culture and Environment of Ancestral Oceanic Society vol. 4. Animals. PL 621. Canberra: Pacific Linguistics.

Sheppard, P.J. 1993. Lapita lithics: Trade, exchange and technology: a view from the Reefs/Santa Cruz. Archaeology in Oceania 28: 121-137. doi.org/10.1002/j.1834-4453.1993.tb00303.x.

Shutler, R. Jr., D.V. Burley, W.R. Dickinson, E. Nelson and A.K. Carlson. 1994. Early Lapita sites: The colonisation of Tonga and recent data from Northern Ha'apai. Oceania 29: 53-68.

Spriggs, M. 1997. The Island Melanesians. Oxford and Cambridge, Massacussetts: Blackwell.

Steadman, D.W. 1998. The Lapita extinction of Pacific Island birds: Blitzkrieg versus slow death. In J.C. Galipaud and I. Lilley (eds), The Western Pacific 5000 to 2000 BP. Noumea: ORSTROM.

Steadman, D.W., A. Plourde and D.V. Burley. 1998. Prehistoric butchery and consumption of birds in the Kingdom of Tonga. Journal of Archaeological Science 29: 571-584. doi.org/10.1006/ jasc.2001.0739.

Summerhayes, G.R. 2001. Lapita in the far west: Recent developments. Archaeology in Oceania 36: 53-63. doi.org/10.1002/j.1834-4453.2001.tb00478.x.

Worthy, T.H. and G. Clark. 2009. Bird, mammal and reptile remains. In G. Clark and A. Anderson (eds), The Prehistory of Early Fiji, pp. 213-230. Terra Australis 31. Canberra: ANU E Press. 
This text is taken from New Perspectives in Southeast Asian and Pacific Prehistory, edited by Philip J. Piper, Hirofumi Matsumura and David Bulbeck, published 2017 by ANU Press, The Australian National University, Canberra, Australia. 